DOI: http://dx.doi.org/10.29303/mandalika.v2i1.1809

\title{
Sebuah Studi Fenomenologi Mengenai Aturan Pindah Ruas Dalam Menyelesaikan Persamaan Linear Matematika
}

\author{
Yosepha Patricia Wua Laja ${ }^{*}$ \\ ${ }^{1}$ Pendidikan Matematika, Fakultas Ilmu Pendidikan, Universitas Timor \\ *yosephalaja@unimor.ac.id
}

\begin{abstract}
This study is designed to discuss a method of linear agreement using the rules of moving segments. This research is a qualitative research by discussing phenomenology. Data were collected by interview technique and focus group discussions. Data sources are 11 prospective mathematics subject teachers and 2 mathematics subject teachers who are postgraduate students of mathematics education at Yogyakarta State University in the 2016/2017 school year. Data analysis using Bokdan and Biglend models is done by reducing data, classifying data and verifying data then giving conclusions. The results show that the rules of moving segments in solving linear equations which are considered as a result of the creativity of teachers in spending mathematics, however, some things that are unacceptable are methods that can be used as alternatives to solving problems.
\end{abstract}

Keywords: phenomenological studies, moving segments, linear equation of mathematics.

\begin{abstract}
Abstrak
Studi ini dirancang untuk meneliti mengenai keesksistensian dari suatu cara atau metode penyelesaian persamaan linear dengan menggunakan aturan pindah ruas. Penelitian ini merupakan penelitian kualitatif dengan pendekatan Fenomenologis. Data dikumpulkan dengan teknik wawancara dan focus group discussion. Sumber data adalah 11 calon guru mata pelajaran matematika dan 2 guru mata pelajaran matematika yang adalah mahasiswa pascasarjana pendidikan matematika Universitas Negeri Yogyakarta tahun ajaran 2016/2017. Analisis data menggunakan model Bokdan dan Biglend yang dilakukan dengan cara mereduksi data, mengklasifikasi data dan memverivikasi data kemudian memberikan kesimpulan. Hasil penelitian menunjukkan bahwa aturan pindah ruas dalam menyelesaikan persamaan linear dianggap merupakan suatu hasil kreatif para guru dalam membelajarkan matematika namun beberapa calon guru tidak menerima metode ini sebagai alternative penyelesaian persamaan linear karena cara ini dianggap 'merusak' hakikat matematika yang merupakan ilmu yang terstruktur.
\end{abstract}

Kata Kunci: studi fenomenologis, pindah ruas, persamaan linear matematika.

\section{PENDAHULUAN}

Creswell (2015: 8) mengungkapkan studi fenomenologi merupakan studi yang berusaha mencari "esensi" makna dari suatu fenomena yang dialami oleh beberapa individu. Lebih lanjut, Creswell (2015) mengemukakan bahwa studi fenomenologis menjadi salah satu jenis penelitian kualitatif. Objek yang dikaji dalam suatu studi fenomenologi adalah fenomena. Untuk memahami suatu fenomena yang ada dalam matematika, maka seorang calon guru ataupun guru perlu membuka diri untuk membuka dan memahami fenomena tersebut (Hasbiansyah, 2005). Fenomena dalam penelitian ini mengenai penggunaan aturan pindah ruas dalam materi persamaan linear yang terkenal di kalangan pendidik dan pelajar.

Matematika merupakan suatu bentuk pemecahan masalah dimana dengan mengajar dan belajar matematika, siswa dapat mengembangkan kemampuan memecahkan berbagai jenis masalah matematika yang kompleks secara luas (Haryani, 2011 ). Dalam memecahkan sebuah masalah matematika diperlukan prosedur atau langkah-langkah sistematis dan terstruktur sehingga sebuah masalah 
matematika dapat terpecahkan dan dapat diperoleh solusinya. Sejalan dengan ini, tujuan pembelajaran matematika adalah melatih cara berpikir yang sistematis, logis, kritis, kreatif dan konsisten (Depdiknas, 2004).

Salah satu bagian dalam pembelajaran matematika adalah aljabar. Ketika seorang siswa duduk di Sekolah Menengah Pertama (SMP) dan diberikan pertanyaan berapakah jumlah dari 2 buah pensil ditambah 5 buah pensil ? atau berapakah jumlah 4 ekor kucing ditambah 2 ekor sapi ?. Pada saat guru memberikan pertanyaan ini, secara tidak langsung siswa sudah mulai diperkenalkan pada pemahaman konsep aljabar, dimana pensil, kucing dan sapi dapat dinyatakan dalam sebuah huruf yang kemudian dalam matematika istilah huruf itu merupakan suatu variabel.

Materi dasar mengenai aljabar diajarkan untuk pertama kalinya di SMP kelas VII. Siswa akan mengalami kesulitan jika tidak memahami dengan baik materi tentang konsep dasar aljabar karena materi aljabar akan dipelajari lagi di Sekolah Menengah Atas (SMA) yang semakin kompleks. Konsep dasar aljabar ini dikemas dalam sebuah pembelajaran mengenai persamaan. Adapun standar kompetensi yang harus dikuasai siswa pada pembelajaran aljabar dikelas VII meliputi: (1) Memahami bentuk aljabar, persamaan dan pertidaksamaan linear satu variabel, (2) Menggunakan bentuk aljabar, persamaan dan pertidaksamaan linear satu variabel, dan perbandingan dalam pemecahan masalah, (Depdiknas, 2006).

Pada hakekatnya pengetahuan awal pada matematika seperti operasi-operasi dasar aritmatika dan aljabar, konsep relasi dan fungsi, serta kemampuan menerjemahkan suatu pernyataan verbal ke dalam bentuk-bentuk aljabar merupakan prasayarat untuk dapat mempelajari satuan-satuan bahasan yang lain. Jika seorang siswa tidak mampu menyelesaikan aljabar dalam sebuah persamaan linear maka siswa tersebut pastinya tidak memiliki kemampuan prasyarat dalam pokok bahasan matematika lainnya. Sebelum mempelajari persamaan, siswa diajarkan terlebih dahulu mengenai koefisien, variabel, faktor, suku sejenis dan suku tak sejenis. Jika siswa sudah membedakan beberapa hal ini maka siswa dihadapkan pada materi tentang persamaan.

Persamaan dalam matematika merupakan kalimat terbuka yang dihubungkan dengan tanda sama dengan (=). Artinya dalam sebuah persamaan memiliki dua ruas yakni ruas yang berada disebelah kiri tanda sama dengan disebut ruas kiri dan ruas yang berada disebelah kanan tanda sama dengan disebut ruas kanan. Di bangku SMP, terdapat beberapa bentuk persamaan yakni persamaan berderajat satu dan persamaan berderajat dua. Contoh persamaan berderajat satu adalah $2 x+5=17$, dengan rincian suku-suku diruas kiri adalah $2 x+5$ dan suku-suku diruas kanan adalah 17.

Tujuan menyelesaikan permasalahan aljabar dalam sebuah persamaan linear adalah mencari nilai yang memenuhi sebuah variabel dari persamaan tersebut. Salah satu cara untuk menemukan nilai sebuah variabel adalah dengan menggunakan persamaan-persamaan yang ekuivalen. Penggunaan cara ini adalah dengan menambah kedua ruas dengan bilangan yang sama atau mengurangi kedua ruas dengan bilangan yang sama dan atau membagi dan mengalikan kedua ruas dengan bilangan yang sama dan bukan nol. Suatu persamaan linear yang kedua ruasnya ditambah, dikurangi, dikalikan atau dibagi dengan bilangan yang sama akan menghasilkan persamaan yang setara (ekuivalen) dengan persamaan semula sehingga persamaan yang baru merupakan bentuk manipulasi aljabar dari persamaan aljabar sebelumnya. 
Fenomena menunjukkan bahwa cara persamaan ekuivalen sering diabaikan oleh para guru dalam menyajikan materi persamaan ini. Hal ini di indikasikan menjadi akibat kesalahan-kesalahan yang dilakukan siswa dalam menyelesaikan persamaan linear. Sejalan dengan ini, beberapa penelitian mengemukakan bahwa kesalahan dalam menggunakan aturan pindah ruas merupakan kesalahan prosedural (Ramadhani,2005; Hadiyanto,F.,R.,dkk, 2016: Oktoviani,V.,dkk,2019: ). Hasil penelitian ini tentunya memberikan bukti bahwa jika langkah-langkah matematika yang sistematis tidak digunakan dengan baik maka siswa akan melakukan kesalahan-kesalahan dalam menyelesaikan aljabar.

Kenyataan sekarang menunjukkan bahwa dalam menyelesaikan sebuah persamaan linear guru cenderung menjelaskan tentang bagaimana caranya untuk mencari nilai sebuah variabel dalam sebuah persamaan dengan cara cepat menggunakan aturan pindah ruas. Cara ini masih menimbulkan pro-kontra. Disatu pihak, cara ini bertentangan dengan tujuan pembelajaran matematika itu sendiri yakni melatih siswa untuk berpikir secara sistematis dengan menggunakan langkahlangkah yang tepat dalam memcahkan masalah matematika. Namun, dilain pihak cara ini jelas memudahkan para siswa untuk belajar sehingga calon guru ataupun guru perlu menanamkan konsep yang sebenarnya kemudian alternative cara lain.

Ramadhani (2015) juga mengungkapkan bahwa penyebab kesalahan siswa dalam menyelesaikan persamaan linier satu variabel adalah: (1) penggunaan "pindah ruas" tanpa mengecek dengan konsep "pindah ruas" yang benar atau (2) kurangnya penguasaan materi aritmetika dasar. Ditambah lagi kenyataan yang penulis dapatkan di lapangan menunjukkan bahwa banyak siswa yang tidak memahami aljabar bahkan hanya sekedar tahu bahwa untuk menyelesaikan sebuah persamaan hanya bisa menggunakan aturan pindah ruas.

Pindah ruas dipakai sebagai cara cepat untuk menyelesaikan suatu persoalan dalam matematika. Penyelesaian persamaan linear dengan menggunakan pindah ruas diyakini dapat mempercepat waktu siswa untuk menyelesaikan soal persamaan. Berdasarkan penelitian yang dilakukan oleh Zain,M.,Idris,M., dan Rizal,M. (2016), siswa diminta untuk menyelesaikan persamaan $6 x-3=7+x$. Mereka akan cenderung menyelesaikan persamaan itu menjadi $6 x-x=7+3$. Ketika guru menanyakan kenapa bisa demikian,mereka akan mengemukakan bahwa pindah ruas membuat beberapa suku membuat tanda berubah. Ketika ditanya lebih lanjut mengapa tanda berubah, mereka pun bingung memberikan jawabannya.

Berdasarkan dari latar belakang di atas maka tujuan dari penulisan studi ini adalah ingin mengemukakan pendapat para calon guru/guru/dosen tentang pandangan mereka mengenai aturan pindah ruas dalam pembelajaran matematika khususnya dalam pembelajaran persamaan matematika yang dikemas dalam sebuah studi kualitatif. Selain itu, penelitian ini sebagai bahan masukan sekaligus penambahan wawasan bagi pendidik matematika dalam mengajarkan bentuk persamaan sehingga terciptalah proses pembelajaran yang efektif dan menyenangkan. Oleh karena itu aturan pindah ruas dapat menjadi salah satu metode cepat maka peneliti tertarik untuk melakukan penelitian dengan judul "Sebuah Studi Fenomenologi mengenai Aturan Pindah Ruas dalam Menyelesaikan Persamaan Linear Matematika". 
DOI: http://dx.doi.org/10.29303/mandalika.v2i1.1809

METODE

Studi ini merupakan studi fenomenologi yang dilakukan dengan pendekatan kualitatif. Studi fenomenologi ini digunakan untuk mendapatkan esensi dari Aturan Pindah Ruas berdasarkan pengalaman dari calon guru maupun guru matematika. Partisipan pertama penelitian ini adalah mahasiswa semester 1 pendidikan matematika pascasarjana Universitas Negeri Yogyakarta angkatan 2016. Partisipan ini dipilih karena para mahasiswa ini adalah calon guru matematika yang berasal dari seluruh wilayah Indonesia. Peneliti tertarik ingin mengetahui seberapa besar eksistensi aturan pindah ruas untuk seluruh wilayah Indonesia.

Teknik pengumpulan dilakukan dengan focused group discussion (FGD) dan wawancara. Bahan FGD dan wawancara meliputi esensi Aturan Pindah Ruas sebagai : 1) Cara cepat dalam menyelesaikan persamaan linear, 2) Hasil kreatif guru dalam membelajarkan matematika, 3) 'Perusak' ciri sistematis dari matematika.

Hasil FGD dan hasil wawancara kemudian direduksi. Hasil reduksi akan ditampilkan dalam bentuk tabel untuk mendapatkan sub-sub tema hingga mendapatkan suatu tema. Analisis data dilakukan dengan menentukan hubungan antartema untuk memperoleh pemahaman mengenai esensi dari Aturan Pindah Ruas menggunakan model Bogdan \& Biklen (1982).

\section{HASIL DAN PEMBAHASAN}

\section{Hasil}

Hasil wawancara yang dilakukan dengan partisipasinya adalah mahasiswa pascasarjana pendidikan matematika UNY 2016 yang berprofesi sebagai guru, calon guru dan calon dosen. Partisipan berasal dari Sumatera, Kalimantan, Jawa dan Nusa Tenggara Timur. Dari hasil wawancara menunjukkan bahwa terdapat empat partisipan yang sangat setuju dengan Aturan Pindah Ruas yakni G3,G4, G7 dan G9. Dan terdapat delapan partisipan yang tidak setuju dengan Aturan Pindah Ruas yakni G1, G5, G6, G8, G10, G11. Selain itu terdapat satu partisipan yakni G12 yang kurang setuju dengan Aturan Pindah Ruas.

\section{Aturan Pindah Ruas sebagai Metode Cepat Penyelesaian Persamaan Linear}

Pada kenyataannya matematika merupakan pelajaran yang masih dianggap sulit oleh seluruh siswa. Sulitnya bidang studi matematika ini dikarenakan kesukaran itu terutama disebabkan oleh beberapa faktor yang berkaitan dengan hakikat matematika. Karena matematika ini sudah dianggap susah oleh siswa maka guru berusaha untuk menciptakan dan meningkatkan minat siswa untuk mempelajari matematika menggunakan cara cepat dan tidak ribet karena langkahlangkah penyelesaiannya yang terlalu panjang. Salah satu langkah cepat yang diajarkan guru dalam menyelesaikan sebuah persamaan linear adalah dengan menggunakan Aturan Pindah Ruas. Para guru akan mengajarkan bahwa untuk mencari nilai variabel dari sebuah persamaan adalah dengan mengumpulkan semua variabel di satu ruas dengan cara merubah tanda. Tanda + berubah menjadi tanda 
- dan tanda - berubah menjadi tanda + . Seperti yang diungkapkan beberapa partisipan.

"Saya adalah seseorang yang mengadopsi istilah pindah ruas ini (G3)"

"Saya menggunakan cara cepat untuk memudahkan anak IPS ini mengerjakan matematika yakni dengan mengumpulkan suku-suku sejenis dengan mengubah tanda - menjadi + dan tanda + menjadi . "(G4)

"Saya sangat setuju dengan pindah ruas karena lebih gampang dicerna oleh siswa"(G7)

"Walaupun sebagai cara cepat siswa juga perlu tahu pindah ruas itu bermulanya darimana, tapi guru cukup seperlu saja menjelaskan tentang mulanya pindah ruas dan selanjutnya siswa harus menggunakan pindah ruas untuk memudahkan pembelajaran matematika”. (G1)

“...pindah ruas ini sering digunakan sehingga supaya akan-anak benar-benar mengerti tentang pindah ruas maka harus diajarkan secara berulang-ulang tentang pindah ruas...”(G7)

“...siswa belum mengerti maka diajarkan secara berulang-ulang tentang cara pindah ruas tersebut..."(G3)

Tabel 1. Hasil Reduksi mengenai Aturan Pindah Ruas sebagai Cara cepat

Sub-tema Hubungan antar sub-tema

Mindest bahwa matematika merupakan mata pelajaran yang sulit

Para calon guru/guru merasa Aturan Pindah

Memindahkan ruas berarti merubah tanda

Pindah ruas sangat membantu para siswa jurusan non IPA

Ruas perlu diajarkan berulang-ulang kepada para siswa agar mindset mereka mengenai susahnya matematika dapat berkuranf.

Pindah ruas gampang dicerna oleh para siswa

Para siswa harus diajarkan secara berulang-ulang

kali mengenai pindah ruas

Para siswa tidak perlu menyulitkan diri untuk

belajar yang susah kalau ada cara yang gampang

Aturan Pindah Ruas ini perlu diterapkan sehingga siswa menganggap matematika itu mudah. Apabila siswa telah menganggap matematika itu mudah maka akan memberikan sebuah pengaruh positif bagi siswa tersebut untuk belajar matematika dan kesulitan siswa akan berkurang. Karena kita ketahui bahwa kesulitan dapat mempengaruhi siswa belajar seperti yang diungkapkan oleh Depdikbud bahwa Hubungan antara kesalahan dan kesulitan dapat diperhatikan pada kalimat "jika seorang siswa mengalami kesulitan maka ia akan membuat kesalahan". Hal tersebut menegaskan bahwa kesulitan merupakan penyebab terjadinya kesalahan. Sehingga aturan pindah ruas diterapkan agar siswa tidak mengalami kesulitan dalam belajar. Oleh karena itu guru cenderung menjelaskan menggunakan langkah-langkah sebagai berikut, pertama kita perlu mengumpulkan suku-suku sejenis pada satu ruas dengan memindahkan suku-suku tersebut pada salah satu ruas dan perlu mengubah tanda. Intinya adalah setiap kita memindahkan suatu suku ke ruas yang lain maka tanda dari suku tersebut akan berubah.

\section{Aturan Pindah Ruas sebagai Hasil Kreatif Guru Membelajarkan Matematika}

Memasuki era milenial saat ini memberikan dampak bagi bangsa Indonesia dalam melakukan berbagai perbaikan dalam berbagai bidang, termasuk di dalamnya bidang pendidikan khususnya pendidikan matematika. Perbaikan ini juga 
ditandai dengan adanya perubahan-perubahan proses pengajaran yang dilakukan oleh para guru dengan tujuan untuk mempermudah siswa-siswanya mempelajari matematika.

Kita semua pasti pernah mendengar istilah pindah ruas. Pindah ruas merupakan salah satu metode yang sering digunakan oleh para guru untuk mempermudah siswa dalam menyelesaikan soal-soal persamaan linear. Pindah ruas ditenarkan oleh para guru-guru Indonesia di era tahun 2000-an. Hal ini menunjukkan bahwa metode ini menjadi bentuk kreatif para guru dalam membelajarkan matematika.

Tabel 2. Hasil Reduksi mengenai Aturan Pindah Ruas sebagai Bentuk Kreatif Guru

\begin{tabular}{lll}
\hline Sub-tema & Hubungan antar tema \\
Para guru mengenal istilah pindah ruas di tahun & $\begin{array}{l}\text { Pindah ruas memberikan bukti bahwa para guru } \\
\text { kreatif dalam membelajarkan matematika }\end{array}$ \\
$\begin{array}{l}\text { 200-an } \\
\begin{array}{l}\text { Dasar dari Aturan Pindah Ruas perlu } \\
\text { ditekankan }\end{array}\end{array}$ \\
$\begin{array}{l}\text { Pindah ruas digunakan tergantung } \\
\text { kegunaannya }\end{array}$ & & \\
\hline
\end{tabular}

Dalam melakukan proses belajar mengajar tidak senantiasa berhasil, seringkali dihadapi masalah-masalah yang mengakibatkan siswa merasa kesulitan dalam belajar. Siswa yang mengalami kesulitan belajar membuat guru menjadi frustasi memikirkan bagaimana menghadapi siswa seperti ini. Oleh karena siswa mengalami kesulitan maka guru harus kreatif menciptakan suasana belajar yang mempermudah siswa dalam belajar. Karena guru kreatif dalam pembelajaran maka Aturan Pindah Ruas menjadi salah satu kekreatifan guru dalam menyelesaikan persamaan linear. Akan tetapi pada awalnya guru harus menjelaskan tentang konsep yang sebenarnya tentang pindah ruas yakni dengan persamaan-persamaan yang ekuivalen. Dan jika siswa dihadapkan pada UN atau sebuah kompetisi matematika maka siswa perlu diajarkan cara cepat untuk menyelesaikan sebuah persamaan.

\section{Aturan Pindah Ruas 'Merusak' Ciri Sistematis dari Matematika}

Jika seorang guru langsung mengajarkan cara menyelesaikan sebuah persamaan dengan menggunakan pindah ruas maka secara tidak langsung siswa tidak dilatih kecerdasannya sehingga siswa menganggap bahwa matematika itu bukanlah sebuah pelajaran yang memberikan kecerdasan tapi matematika hanya berupa sekumpulan materi dimana langkah-langkah penyelesaiannya menggunakan rangkaian aturan tanpa alasan karena dilakukan tanpa sadar dan tidak mempengaruhi situasi akhir penerimaan. Sehingga beberapa partisipan mengungkapkan bahwa mereka tidak setuju dengan metode penyelesaian menggunakan istilah pindah ruas dan jika mereka menjadi guru maka mereka tidak akan menggunakan istilah pindah ruas ini dalam menyelesaikan persamaan linear. Beberapa dari partisipan mengaku bahwa mereka mengetahui metode dengan menggunakan istilah pindah ruas ini dari para guru mereka sewaktu mereka berada dibangku sekolah. Seperti yang diungkapkan beberapa partisipan berikut :

“...Saya bukan seseorang yang mengadopsi istilah pindah ruas...”(G2)

“...Tapi setelah saya tau pindah ruas itu salah dari dosen S1 saya bahwa pindah ruas itu salah...”(G5)

“...seharusnya menyelesaikan persamaan dengan memenuhi beberapa aksioma-aksioma..."(G6)

"...Pindah ruas itu buruk bagi saya karena tidak ada istilah pindah ruas dalam buku belajar matematika.."(G8)

"... guru yang berspekulasi tentang pindah ruas sehingga diajarkan ke anak dan anak menggunakan cara pindah ruas tersebut untuk menyelesaikan soal matematika..."(G6) 
"saya mengajarkan mereka bahwa pindah ruas itu salah, seharusnya adalah dengan menjumlahkan, mengurangkan ataupun mengalikan dengan sebuah bilangan yang sama untuk kedua ruas.."(G10)

“...step by step langkah tiap langkah yang sesuai dengan konsep matematika dan saya tidak akan menggunakan istilah tersebut..."(G8)

Seperti yang telah diungkapkan sebelumnya, bahwa matematika merupakan ilmu yang sistematis, terstruktur. Sehingga guru perlu menyampaikan kepada para siswa bahwa untuk menentukan penyelesaian dari sebuah persamaan adalah dengan menggunakan aturan-aturan aksioma-aksioma yang berlaku dalam matematika yakni dengan mengalikan atau menjumlahkan atau mengurangkan dengan sebuah bilangan yang sama. Misalkan sebagai berikut.

$$
\begin{aligned}
& 6-3=7+x \\
& 6 x-3+3=7+x+3 \\
& 6 x=10+x \\
& 6 x-x=10+x-x \\
& 5 x=10 \\
& 5 x(1 / 5)=10(1 / 5) \\
& x=2
\end{aligned}
$$

Beberapa partisipan juga memberikan solusi jika mereka tidak menggunakan metode dengan menggunakan istilah pindah ruas maka mereka akan mengajarkan dengan cara sebagai berikut:

“...Kalau saya akan mengajar tentang penyelesaian persamaan linear maka pertama saya akan mengarahkan anak-anak untuk mencari inti dari sebuah persoalan matematika. Misalkan jika ditanya tentukan nilai $x$ maka saya tentang tujuan inti dari penyelesaian persamaan linear. Sehingga pada ujung penyelesaian akan saya tuliskan $x=\cdots$ dan selanjutnya siswa yang melanjutkan pekerjaannya. Jika nilai $x$ yang dicari ada diruas kiri maka pindahkan suku-suku yang memiliki $x$ diruas kiri dan bilangan-bilangan diruas kanan dengan mengikuti aturan ,tanda + menjadi - dan tanda - menjadi positif..."(G1)

"...Langkah-langkah yang saya gunakan adalah dengan menggunakan aksioma-aksioma yang berlaku yakni menggunakan sifat-sifat dengan menjumlahkan, mengurangkan ataupun mengalikan dengan sebuah bilangan yang sama..."(G6)

"...karena mereka tidak mengerti kenapa bisa tanda + dipindahkan menjadi - dan kenapa - kalau dipindahkan menjadi +. Sehingga saya akan menggunakan cara penyelesaian dengan menjumlahkan, mengurangkan ataupun mengalikan kedua ruas..."(G11)

Tabel 3. Hasil Reduksi mengenai Aturan Pindah Ruas Merusak Ciri Sistematis Matematika

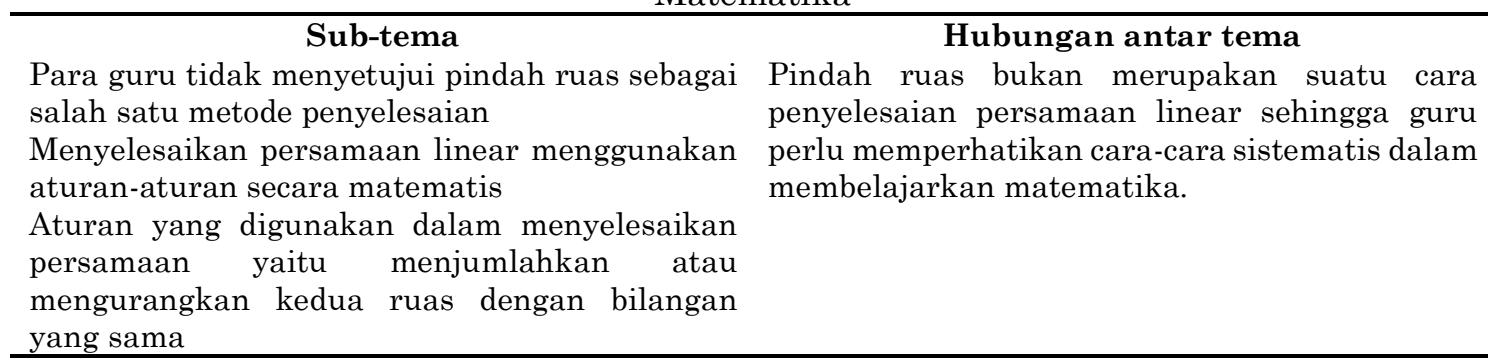

\section{Pembahasan}

Sesuatu yang tampil dalam suatu kesadaran merupakan suatu fenomena. Sebuah fenomena tentu berdasarkan pengalaman yang dialami oleh beberapa individu dengan melibatkan apa yang mereka alami dan bagaimana mereka mengalaminya. Melihat subjek penelitian yang merupakan calon guru dan guru yang berasal dari berbagai daerah di Indonesia, mereka tidak asing dengan aturan pindah ruas dalam menyelesaikan suatu persamaan. Hal ini jelas menunjukkan bahwa fenomena mengenai aturan pindah ruas pernah dipelajari oleh kita semua. 
DOI: http://dx.doi.org/10.29303/mandalika.v2i1.1809

Menurut Moustakes (1994), kesadaran adalah realitas absolut sedangkan yang muncul di dunia adalah suatu produk belajar. Bila dikaitkan pada penelitian ini, kesadaran adalah realita mengenai cara menyelesaikan persamaan linear menggunakan suatu istilah pindah ruas yang telah dipelajari oleh subjek belajar. Lebih lanjut pindah ruas ini merupakan produk belajar dari para guru untuk membelajarkan matematika. Produk belajar ini menjadi hasil kreatif para guru dalam membelajarkan matematika. Hasil kreatif yang membantu siswa dalam belajar untuk menyelesaikan persamaan linear secara cepat. Hasil kreatif ini didukung hasil wawancara yang dilakukan dengan beberapa partisipan yang mengaku bahwa yang memperkenalkan aturan pindah ruas itu adalah guru-guru diera tahun 2000-an.

Matematika dikenal sebagai suatu mata pelajaran yang membutuhkan penalaran yang sistematis (NCTM, 2000 ). Artinya dengan membantu siswa untuk belajar prosedur yang sistematis akan memberikan dampak bagi proses berpikir para siswa. Fenomena menunjukkan bahwa aturan pindah ruas ini melangkahi sistematis dari matematika yang bisa berdampak pada kesalahan konsep. Karena konsep matematika yang tersusun secara hierarki, maka dalam belajar matematika tidak boleh ada langkah/tahapan konsep yang dilewati. Matematika hendaknya dipelajari secara sistematis dan teratur serta harus disajikan dengan struktur yang jelas dan harus disesuaikan dengan perkembangan intelektual siswa serta kemampuan prasyarat yang telah dimilikinya. Dengan demikian pembelajaran matematika akan terlaksana secara efektif dan efisien.

Lebih lanjut, Hall (2002) menyebutkan bahwa kesalahan dalam penggunaan aturan pindah ruas akan menyebabkan kesalahan lanjutan dalam pembelajaran matematika. Kesalahan itu antara lain kesalahan perualangan distribusi, kesalahan penukaran penjumlahan dan transpose. Salah satu kesalahan yang paling sering dilakukan adalah kesalahan penukaran penjumlahan. Dimana hampir setiap siswa akan melakukan kesalahan ini (Prasanti,2015; Nurizzbaeni,dkk, 2019 ). Misalkan siswa diminta untuk menyelesaikan persamaan $2 x+3=x+8$ dengan berpikir bahwa kemungkinan para siswa akan memindahkan 3 ke ruas kanan dan mengubah tandanya. Aturan ini perlu dipertanyakan, mengapa 3 yang dipindahkan dan mengapa tandanya berubah.

Kesalahan dalam aturan pindah ruas mengenai penukaran penjumlahan dapat menyebabkan kesalahan lain yang lebih fatal. Misalkan siswa diberikan soal mengenai $-6 x=12$, oleh siswa yang sering melakukan kesalahan penukaran penjumlahan maka mereka akan berpikir untuk menyelesaikan dengan cara $x=12+6$ sehingga $x=18$ karena para siswa mengira memindahkan -6 dari ruas kiri akan menjadi +6 di ruas kanan (Sadida,2019). Ini merupakan kesalahan kanselasi atau menurut Hall (2002), kesalahan ini merupakan kesalahan transpose. Para siswa perlu diajak untuk berpikir mengapa aturan bisa demikian karena nanti pada kenyataannya siswa hanya akan menggunakan aturan pindah ruas sebagai prosedur hafalan yang digunakan dalam menyelesaikan persamaan (Sari,Sudirman \& Chandra, 2018) . Sependapat dengan ini, Knuth (2000), menyebutkan bahwa sebagian siswa menggunakan prosedur sebagai aturan rutin yang biasa dilakukan tanpa memahami alasan penggunaannya. Sehingga jika siswa hanya sekedar tahu pindah ruas berubah tanda maka sebenarnya belajar matematika itu hanya berupa kumpulan-kumpulan aturan yang tak bermakna.

Di lain pihak, Bunga,dkk (2015) ; Suciyani (2012) mengemukakan bahwa kesalahan konsep dalam menggunakan prosedur tertentu dalam pembelajaran aljabar berada dalam kategori sedang 54,47\%. Hal ini menunjukkan guru harus 
meminimalkan kesalahan prosedural agar siswa benar-benar memahami tentang sebuah konsep persamaan linear ditingkat dasar yakni SMP. Karena setelah mempelajari persamaan, para siswa akan mempelajari pertidaksamaan. Misalnya $2<(x-2)<6$, apabila $(-2)$ pindah ruas maka kemungkinan mereka akan bingung untuk memindahka (-2) ke ruas kiri atau ruas kanan. Akan tetapi ketika siswa diajarkan untuk menambah 2 semua ruas maka siswa tidak akan mengalami kesulitan dalam menyelesaikan persoalan tersebut. Karena siswa akan menuliskan $(2+2)<(x-2+2)<(6+2)$ dan diperoleh hasil akhir $4<x<8$.

Matematika adalah sebuah kesepakatan berdasarkan teorema-teorema ataupun aksioma-aksioma yang berlaku. Berdasarkan pedoman yang diperoleh peneliti dari buku matematika, cara menyelesaikan persamaan linear yang benar dan tepat adalah :

1. Menambah atau mengurangi kedua ruas persamaan dengan bilangan yang sama $x=2$

2. Mengalikan atau membagi kedua ruas persamaan dengan bilangan yang sama

Langkah-langkah ini adalah langkah yang dibenarkan dalam matematika. Jadi sebaiknya guru menggunakan langkah-langkah yang tepat ini dalam menyelesaikan persamaan linear dan mulai untuk menghilangkan aturan pindah ruas dalam pembelajaran matematika karena aturan pindah ruas bukanlah aturan yang berlaku dalam matematika (Koem,2014). Seperti yang diungkapkan oleh Hutaean,dkk (2018) yang menggunakan permainan Android Dragon Box untuk meminimalisis penggunaan aturan pindah ruas dalam menyelesaikan persamaan linear. Sehingga kesalahan siswa mengenai konsep menyelesaikan sebuah persamaan linear dapat diminimalisir.

\section{PENUTUP}

\section{Simpulan}

Berdasarkan hasil analisis di atas mengenai studi fenomenologis pindah ruas dalam mempelajari aljabar dapat ditarik kesimpulan bahwa dalam menyelesaikan sebuah persamaan linear sebaiknya guru dan siswa menggunakan langkah-langkah yang dibenarkan dalam matematika berdasarkan aturan-aturan penyelesaian yang tepat sehingga siswa dapat berpikir secara sistematis dan tepat walaupun terdapat cara lain yang merupakan cara cepat dapat dijadikan sebagai alternatif.

\section{Saran}

Saran dari peneliti jika diantara para pembaca sekalian masih menerapkan atau menemukan guru yang masih menggunakan Aturan Pindah Ruas dalam menyelesaikan persamaan linear maka perlu diberi arahan dan teguran secara halus dan sebaiknya diperbaiki.. 
DOI: http://dx.doi.org/10.29303/mandalika.v2i1.1809

\section{DAFTAR PUSTAKA}

Depdiknas. (2006). Standar Isi Mata Pelajaran Matematika SD/MI dan SMP/MTs (Permendiknas Nomor 22 Tahun 2006). Jakarta: BSNP

Depdiknas. (2006). Model Kurikulum Tingkat Satuan Pendidikan dan Model Pengembangan Silabus Mata Pelajaran SMP/MTs. Jakarta: BSNP

Bunga,dkk. (2015). Analisis Kesulitan Siswa dalam Menyelesaikan Soal Materi Aljabar Siswa Kelas VIII SMP Negeri 2 Bangil. Kadikma. 6(2) : 119-130

Creswell,John W. (2015). Penelitian Kualitatif \& Desain Riset (Terjemahan). Yogyakarta : Pustaka Belajar

Hadiyanto, Fahrur Rozi, Hery Susanto, and Abd Qohar. (2016). Identifikasi Kesalahan Siswa Kelas VII Dalam Menyelesaikan Soal Geometri. Conference Paper. Malang: Universitas Malang

Hall,R.D.G. (2002). An Analysis of Errors Made in the Solution of Simple Linear Equations. Philosophy Of Mathematics Education Journal 15 page (1-64).

Haryani,Desi. (2011). Pembelajaran Matematika dengan Pemecahan Masalah untuk Menumbuhkembangkan Kemampuan Berpikir Kritis Siswa. Prosiding Seminar Nasional Penelitian, Pendidikan dan Penerapan MIPA,Fakultas MIPA. Yogyakarta : Universitas Negeri Yogyakarta.

Hasbiansyah,O. (2005). Pendekatan Fenomenologi: Pengantar Praktik Penelitian dalam Ilmu Sosial dan Komunikasi. Terakreditasi Dirjen Dikti, SK. No. 56/DIKTI/Kep/2005.

Hutaean, Y., \& Kusumawati, R. (2018, February). Pemanfaatan Permainan Android Untuk Penanaman Konsep Penyelesaian Persamaan Linear Siswa SMP Kelas VII. In Prosiding Seminar Nasional Pendidikan Matematika Etnomatnesia.

Knuth, E. (2000). Understanding Connections between Equations and Graphs. The Mathematics Teacher, 93(1), 48-53. Retrieved from http://www.jstor.org/stable/27971259

Koem, Sri Wahyuni. (2014). Analisis Kesalahan Siswa Dalam Menyelesaikan SoalSoal Matriks Pada Siswa Kelas XII SMA (Suatu Penelitian di SMA Negeri 1 Sumalata Kelas XII IPA). Other Thesis. Gorontalo: Universitas Negeri Gorontalo.

Moustakas,Clark. (1994). Phenomenological Research Methods. New Delhi: Sage Publications.

Nurrizbaeni, N., \& Setiawan, W. (2019). Analisis Kemampuan Pemecahan Masalah Matematik Siswa Kelas X Pada Materi Persamaan Dan Pertidaksamaan Nilai Mutlak. Journal on Education, 1(3), 327-336.

Oktoviani,V.,Wiris,L.,W., dan Ferdianto,Ferry. (2019). Analisis Kemampuan Pemahaman Matematis Siswa SMP pada Materi Sistem Persamaan Linear Dua Variabel. Edumatica. 9(1): 39 - 46

Prasanti,V. M. W. (2015). Analisis Kesalahan Siswa Kelas VII A SMP Kanisius Kalasan Tahun Ajaran 2014/2015 dalam Menyelesaikan Soal-Soal Persamaan Linear Satu Variabel. Universitas Sana Darma. 
Volume 2 Nomor 1, Juni 2020

DOI: http://dx.doi.org/10.29303/mandalika.v2i1.1809

Ramadhani. (2015). Analisis Kesalahan Siswa Kelas VIII SMP pada Materi Aljabar serta Proses Scaffolding-nya. Yang diakses melalui karya-ilmiah.um.ac.id. 1(1)

Sadida, Eky Karimatun Nisa. (2019). Penerapan media pembelajaran Quipper School untuk mengatasi Miskonsepsi siswa pada Aljabar. Undergraduate thesis. Surabaya :UIN Sunan Ampel Surabaya.

Sari, Fadhila Kartika, Sudirman Sudirman, and Tjang Daniel Chandra.(2018). Proses Koneksi Matematis Siswa SMP dalam Menyelesaikan Soal Cerita. Jurnal Pendidikan: Teori, Penelitian, dan Pengembangan 3.6 (2018): 715-722

Suciyani,E. (2012). Ekuivalen: Identifikasi Kesulitan Siswa SMP dalam Melakukan Operasi Aljabar dan Menguraikan Bentuk Aljabar ke dalam Faktor. Portal Garuda. 137-149

Zain,M.,Idris,M., dan Rizal,M. (2016). Analisis Pemecahan Masalah Aljabar Siswa Kelas VIII SMP Negeri 3 Palu. Jurnal Elektronik Pendidikan Matematika Tadulako. 3(3): 358-372 